\title{
OS EQUÍVOCOS DA NOÇÃO DE "REGIÕES QUE EXPLORAM REGIÕES": CRÍTICA AO CONCEITO DE TRANSFERENCIA GEOGRÁFICA DE VALOR DE EDWARD SOJA*
}

\author{
Luis Lopes Diniz Filho**
}

\begin{abstract}
RESUMO
Este artigo levanta algumas críticas teóricas ao conceito de transferência geográfica de valor na forma como este é trabalhado por Edward Soja em seu livro Geografias Pós-Modernas: a reafirmação do espaço na teoria social crítica. Seguem, basicamente, duas linhas de argumentação: a) demonstrar a incompatibilidade entre a teoria do valor e as tentativas de caracterizar o fenômeno do desenvolvimento desigual como produto de certos mecanismos de exploração centro-periferia; $b$ ) indicar que os esforços desse autor para provar a existência de regiões que exploram regiões constituem uma forma de fetichismo do espaço.

No final do texto, apresenta-se uma proposta de análise alternativa à de Soja, a partir de outras interpretações do marxismo e da Geografia sobre a temática do desenvolvimento desigual.
\end{abstract}

\section{AS VELHAS TEORIAS DAS TROCAS DESIGUAIS NO CONTEXTO DA "GEOGRAFIA PÓS-MODERNA".}

Para que se possa tecer uma crítica abrangente sobre o conceito de "transferência geográfica de valor", tal como este é definido pelo geógrafo americano Edward Soja, faz-se necessário antes recuperar algumas das conclusões básicas desenvolvidas em seu livro "Geografias Pós-Modernas", a fim de compreender a função desempenhada por esse conceito dentro do projeto teórico-metodológico elaborado pelo autor em questão.

O ponto de partida dessa obra é a tese de que a crítica marxista ao capitalismo tem despre- zado historicamente a importância do espaço como objeto de análise e, mais ainda, como esfera da realidade dotada de uma "dialética" própria. A influência da filosofia do século XIX sobre o marxismo e, de forma mais ampla, sobre todo o pensamento social do século $X X$, concedeu à história o status de categoria central para o entendimento dos processos sociais e suas contradições, relegando o espaço ao papel de mero

(*) A primeira versão deste texto foi apresentada como trabalho de aproveitamento no curso "Ideologias Geográficas e Políticas Territoriais na América Latina", ministrado pelo Prof. Antonio Carlos Robert de Moraes. Para chegar à sua forma final, contou com as críticas e sugestões do economista Armando Barros de Castro. (**) Analista de Projetos da Fundação Seade, atualmente licenciado para desenvolvimento de tese de doutorado como bolsista da Fapesp. 
reflexo da sociedade, instância passiva e subordinada aos processos sociais. Em virtude disso, todas as análises econômicas pautadas por um enfoque mais incisivo na espacialidade do desenvolvimento capitalista, tais como os estudos sobre o subdesenvolvimento e a dependência, acabaram sendo criticadas pelo modo como teriam tentado atribuir ao espaço qualidades que pertenceriam unicamente à esfera da sociedade e da história ${ }^{1}$.

Essa forma de pensar o espaço e a sociedade, dentro do que Soja denomina de "teoria social crítica", teria influenciado negativamente o processo de renovação da Geografia. Ao assumir o postulado de que os processos e contradições sociais só são inteligíveis na perspectiva da luta de classes, em seus desdobramentos históricos, a Geografia moderna se viu na impossibilidade de desenvolver uma teoria da sociedade capitalista que colocasse o espaço como dimensão essencial da própria estrutura do capitalismo e de suas contradições. O espaço, assim como a história, teria uma dialética, e o medo dos geógrafos críticos em fetichizar o espaço teria levado a essa limitação dos horizontes teóricos da Geografia: incapaz de formular uma crítica social fundada essencialmente no estudo do espaço e das relações deste com a sociedade, essa disciplina permaneceria condenada a ser um simples apêndice da teoria social crítica.

Para superar esse impasse entre o desejo de construir uma crítica social apoiada na análise do espaço e o temor de resvalar para o determinismo ou fetichismo espacial, Soja propõe uma reformulação teórico-metodológica da Geografia, que ele desenvolve a partir da crítica ao historicismo exacerbado e estreito da "ortodoxia

(1) SOJA, Edward W. Geografias pós-modernas: a reafirmação do espaço na teoria social crítica. Rio de Janeiro, Jorge Zahar, 1993, p. 128-129. marxista" e, simultaneamente, através da mobilização de perspectivas filosóficas e teóricas que, embora muito diferentes, convergiriam no sentido de demonstrar o papel ativo das configurações espaciais na estruturação da sociedade contemporânea.

Entre as várias teorias recuperadas por Soja no intuito de revalorizar a análise do espaço, figuram os estudos sobre o subdesenvolvimento e a dependência, gerados nas décadas de 60 e 70 . Segundo ele, autores como Wallerstein, Gunder Frank, Arghiri Emmanuel, bem como os economistas ligados à CEPAL, tiveram o mérito de estimular o debate em torno do desenvolvimento desigual e as relações centro-periferia, mas não teriam levado suas conclusões até as últimas conseqüências por receio de ferir o primado analítico da luta de classes como motor da história. Mesmo no âmbito da Geografia, os estudos realizados por David Harvey e outros geógrafos modernos, sob inspiração desses debates, teriam demonstrado a hesitação dos autores em radicalizar suas posições sobre a importância da análise espacial do capitalismo, motivada por idêntico receio de incorrer num determinismo geográfico a-histórico. Somente Henri Lefebvre e Ernest Mandel teriam ousado colocar a geografia do capitalismo e a lógica do desenvolvimento desigual como elementos fundamentais para a compreensão da sociedade capitalista, razão pela qual seus estudos teriam sido parcialmente deixados de lado dentro da teoria social crítica ${ }^{2}$.

Nesse contexto, recuperar a proposição radical destes últimos, desenvolvendo-a, é a tarefa que Soja coloca como essencial para realizar uma crítica renovadora do marxismo, operada mediante a "espacialização" das teorias de Marx sobre a lógica de funcionamento do modo de pro-

(2) Ibidem, p. 72-73 e 104-105. 
dução capitalista. Assim seria possível retirar esse arcabouço teórico geral de sua forma excessivamente abstrata, conferindo-lhe maior concretude espaço-temporal e abrindo caminho para a construção de um "materialismo histórico-geográfi$\mathrm{Co}^{\prime \prime}$. Com essa emancipação do pensamento crítico em relação ao historicismo ${ }^{3}$, seriam também satisfeitas algumas condições necessárias para criar uma nova perspectiva para os estudos geográficos (a qual já estaria emergindo), denominada pelo rótulo de "geografia humana crítica pósmoderna"4.

Para compreender de que modo Soja procura dar corpo a esse ambicioso projeto, é preciso começar pela análise das teses que ele desenvolve a partir da recuperação das proposições de Lefebvre e Mandel (sobretudo deste último). Segundo ele, os estudos desses autores contribuem para superar a idéia de que as contradições do capitalismo são produzidas unicamente pela dialética das relações capital-trabalho, pois colocam a espacialidade do desenvolvimento capitalista como elemento igualmente importante para a compreensão do funcionamento e das contradições desse modo de produção. A descrição das leis gerais do movimento do capital indicariam a efemeridade do capitalismo, sistema fadado a

(3) No livro de Soja, o "historicismo" aparece como uma postura filosófica que entroniza a perspectiva do tempo histórico como único método válido para a compreensão dos fenômenos sociais, estando assim estreitamente ligado à "imaginação sociológica". Contrapõem-se, assim, à "imaginação geográfica", que pensa a sociedade pela ótica do espaço, embora sem negar a historicidade dos processos sociais. Na literatura sobre o processo de desenvolvimento, contudo, o termo "historicismo" costuma ser empregado de outra maneira, designando certas linhas de pensamento que, ao invés de buscarem construir uma teoria geral para explicar a gênese e difusão do capitalismo, preferem analisar as experiências históricas de desenvolvimento de cada país. Ver: HIRSCHMAN, Albert O. "Suavidade, Poder e Fraqueza da Sociedade de Mercado". In: A economia como ciência moral e política. São Paulo, Brasiliense, 1986.

(4) SOJA, E. W. op. cit., p. 93. autodestruir-se de modo iminente. Para entender como ele tem sobrevivido, seria preciso pensar sua espacialidade:

"Devemos começar, mais uma vez, pela fecunda afirmação lefebvreana de que o capitalismo foi capaz de sobreviver e de alcançar um 'crescimento' através da ocupação de um espaço (...). A isso acrescentamos a especificação mandeliana de que a sobrevivência do capitalismo (...) [depende] da diferenciação do espaço ocupado em regiões 'super-desenvolvidas' e 'sub-desenvolvi$\operatorname{das}^{\prime}(. . .)^{\prime \prime 5}$.

O mecanismo através do qual a desigualdade geográfica do desenvolvimento permitiria superar (ou pelo menos retardar) a tendência autodestrutiva do capitalismo seria inerente ao próprio funcionamento da economia de mercado. Não obstante as enormes assimetrias existentes entre as várias regiões do globo (em termos de composição orgânica do capital, taxa de lucro, e outras) todas elas estariam integradas por um único mercado mundial. Desse modo, os fluxos de mercadorias, de mão-de-obra e de capital entre essas regiões estabeleceriam um complexo sistema de trocas desiguais, mediante o qual ocorreria uma transferência líquida de parte do valor produzido nas regiões "sub-desenvolvidas" para as regiōes "super-desenvolvidas" ${ }^{\text {. A }}$. reiteração desse processo no mercado seria responsável assim pela geração de super-lucro, já que permitiria a determinados setores, empresas e classes sociais dominantes (sediadas em certas regiões) auferir ganhos acima da taxa média de lucro ${ }^{7}$. $\mathrm{O}$

(5) Ibidem, p. 130.

(6) Soja se utiliza da expressão "trocas desiguais" numa referência explícita às teses que se desenvolveram na década de 70 em torno desse conceito. Ressalva, porém, que o mecanismo das trocas desiguais não opera apenas na esfera do comércio internacional (como se pensava predominantemente naquela época), mas sim num âmbito multiescalar. Ibidem, p. 142.

(7) Ibidem, p. 139. 
conceito de transferência geográfica de valor cumpriria assim a função de expressar esse fenômeno, como se conclui pelo seguinte enunciado:

“(...) a transferência geográfica do valor é o mecanismo ou processo através do qual uma parte do valor produzido em dada localidade, área ou região é realizada em outra, somando-se à base de acumulação localizada da região receptora. Essa transferência funciona em dois níveis. O primeiro deles, e o 'mais profundo' em termos da estrutura exposta, é a transferência de valor decorrente das diferenças geográficas dos sistemas de produção e dos processos de trabalho associados - a espacialização simples da transferência de valor de Marx entre as firmas e setores. [O segundo nível] (...) abrange vários processos: a 'drenagem cerebral' de migração seletiva, a exportação líquida de lucros, emolumentos, direitos, etc. sobre as 'ajudas' recebidas, a transferência de controle direto do capital periférico para empresas multinacionais sediadas nos países centrais, as técnicas de transferência da determinação de preços nos conglomerados multinacionais (ou nas empresas de localização múltipla) e, em particular, a ampliação da troca desigual decorrente das diferenças de mercado nas relações de troca de mercadorias $(. . .)^{\prime \prime 8}$.

Desses dois níveis de transferência de valor, é o primeiro que constitui o aspecto mais importante da teorização elaborada por Soja para reafirmar o espaço no contexto da teoria crítica - pelo menos no que tange à economia política -, já que ele é apresentado pelo autor como processo intrínseco à acumulação de capital e à luta de classes: eliminar esse nível de transferência é impossível sem destruir o próprio capitalismo.

Apoiada sobre tais alicerces teóricometodológicos, em que consiste, afinal, a "geografia pós-moderna" postulada por Edward Soja? Ao

(8) Ibidem, p. 140. menos no que diz respeito à problemática regional e urbana, pode-se afirmar que sua proposta se assenta numa determinada leitura marxista do capitalismo que afirma existir um sistema multiescalar de exploração inter-regional análogo às relações de exploração e dominação que se entabulam entre a burguesia e o proletariado?. Daí os extensos elogios de Soja a autores marxistas como Mandel e Lefebvre ${ }^{10}$, verdadeiros precursores dessa nova Geografia. Já os marxistas não convencidos pelas teses da exploração entre regiões podem ser tranqüilamente rotulados e obscurecidos pelo epíteto de "ortodoxos".

Entretanto, procuraremos demonstrar que, não obstante a inegável excelência dos estudos realizados por Soja acerca da "cidade-região" de Los Angeles, seu projeto teórico apresenta uma série de fragilidades e incoerências, cuja origem reside na aceitação de várias teses controvertidas geradas no seio do marxismo (ou sob inspiração dele) como se fossem verdades mais ou menos evidentes.

\section{PROBLEMAS TEÓRICOS DA NOÇÃO DE "TRANSFERÊNCIA DE VALOR" EM ESCALA INTERNACIONAL}

Embora Edward Soja recorra largamente à teoria marxista do valor para fundar as bases do "materialismo histórico-geográfico", é preciso

\section{(9) Ibidem, p. 144.}

(10) Nesse sentido, a proposta do autor não chega a ser inovadora, como já foi destacado numa excelente resenha de sua obra: “(...) seu intento [de Soja] em reafirmar a dimensão espacial, coloca-nos diante de temas que muitas vezes já estamos acostumados a discutir à luz da teoria social crítica. É o que acontece, por exemplo, quando o autor aborda a questão da reestruturação urbana e regional. (...) As contribuiçōes de determinados autores, bastante citados nos estudos mais recentes de geografia urbana e regional, são reafirmadas". TRINDADE JR., Saint-Clair Cordeiro da. "Resenha Bibliográfica: Geografias Pós-Modernas: a Reafirmação do Espaço na Teoria Social Crítica". Boletim Paulista de Geografia, n. 74, 1996, p. 103. 
notar que a tese da exploração inter-regional não se enquadra facilmente nos princípios gerais dessa teoria. Isso se revela, por exemplo, quando ele assume o pressuposto de que a participação das regiões no mercado mundial engendra necessariamente mecanismos de transferência geográfica de valor - dadas as grandes disparidades regionais, em termos de composição orgânica do capital, taxas de lucro, etc. - sem discutir os problemas teóricos subjacentes a essa afirmação.

Com efeito, a operação da teoria do valor pressupõe a vigência de condições técnicas de produção e de níveis de produtividade do trabalho razoavelmente homogêneas, as quais não podem ser encontradas em escala internacional. Portanto, as profundas disparidades verificadas entre países e regiões, ao invés de evidenciarem o funcionamento de certos mecanismos de exploração centro-periferia, indicam sim a impossibilidade de estabelecer a existência de transferências de valor através do comércio internacional de mercadorias dotadas de diferentes quantidades de "valor-trabalho". Para que se possa compreender por que isso ocorre, é preciso lembrar o papel crucial que o conceito de "trabalho homogêneo" desempenha dentro da teoria do valor, visto que:

"Seu modelo [de Marx] se baseia, entre outros, no pressuposto do trabalho homogêneo, vale dizer, a diversidade dos trabalhos concretos pode ser homogeneizada por processos objetivos que permitem pensar um trabalho tecnicamente complexo como a potencialização do trabalho mais simples. Só assim a teoria do valor trabalho tem condições de atuar e fornecer a medida objetiva da exploração capitalista. Isto supõe que o progresso tecnológico se infiltra por todo o sistema como mancha de óleo, todos os produtores dum

(11) GIANNOTTI, José Arthur. A Sociabilidade Travada. Novos Estudos CEBRAP, n. 28, 1990, p. 53. mesmo setor tendo acesso a ele dentro de um prazo razoável"11.

Ora, o que se constata em âmbito internacional é justamente o acentuado grau de heterogeneidade das condições técnicas de produção e dos níveis de produtividade do trabalho vigentes entre os países (mesmo que se restrinja a comparação apenas àqueles do chamado "Primeiro Mundo"), como já vinha sendo apontado por críticos das teorias do intercâmbio desigual desde a década de $70^{12}$. E uma vez que as condições de produção e de trabalho não tendem à perequação, o pressuposto do trabalho homogêneo não se realiza, pois fica impossível estabelecer uma produtividade média que opere como medida objetiva da exploração do trabalho. Na ausência desse parâmetro, a noção de transferência de valor acaba ficando comprometida, pois não se pode nem mesmo determinar o "tempo de trabalho socialmente necessário" para a produção das mercadorias comercializadas internacionalmente.

Estudos mais recentes sobre a questão da dependência, partindo igualmente das grandes assimetrias sócio-econômicas internacionais, levantam ainda mais algumas implicações das teorias do intercâmbio desigual problemáticas do ponto de vista do marxismo, como se pode verificar pelas objeções de Thomas Coutrot às idéias de Arghiri Emmanuel:

"(...) não é legítimo aplicar de modo mecânico ao nível internacional um esquema concebido por Marx para explicar a dinâmica da acumu-

(12) "(...) todas as mais recentes e relevantes investigações sobre 0 desenvolvimento da chamada produtividade do trabalho, sobre a 'lacuna tecnológica' entre EUA e Europa ocidental, e sobre a propagaçāo de inovações técnicas decisivas no processo de produção nos ramos mais importantes do mercado mundial provam que não se pode falar de uma equalização internacional das condições (técnicas) médias, sob as quais é despendido o trabalho nos ramos mais importantes do mercado mundial". SCHOELLER, Wolfgang. Subdesenvolvimento e Troca Desigual no Mercado Mundial. Estudos CEBRAP, n. 22, s.d. 
lação ao nível de determinada formação social. Marx queria explicar por que o capital não fugia sistematicamente dos setores de alta composição orgânica do capital (que utilizam relativamente pouca mão-de-obra e portanto criam pouca maisvalia) em benefício dos setores de baixa composição orgânica. Ele queria portanto fundamentar teoricamente a unidade das condições de valorização do capital ao nível de uma formação social determinada (...). Não faz o menor sentido transpor esse esquema para o nível internacional, que por definição corresponde a uma heterogeneidade fundamental das condições de valorização do capital, como o indica por exemplo a existência de enormes desníveis salariais.

Na concepção marxista (...) é perfeitamente normal uma situação onde uma nação A conhece uma taxa de lucro muito maior que uma nação $B$, sem que no entanto os capitais se dirijam maciçamente para a nação $\mathrm{A}$ até equilibrar as taxas de lucro: determinantes estruturais, como a dimensão insuficiente do mercado interno, a ausência de mecanismos de regulação social, a insegurança econômica e política, podem determinar movimentos dos capitais totalmente diversos dos que uma visão puramente matemática poderia antecipar" ${ }^{\prime \prime 13}$.

Postura muito semelhante a essa é adotada ainda pelo geógrafo Claudio Egler, que tece críticas contundentes (embora apenas de passagem) a determinadas versões da teoria das trocas desiguais surgidas na década de 70 . Segundo ele, os autores que pensavam ser possível a transferência de valor-trabalho entre diferentes sistemas econômicos nacionais, via intercâmbio desigual, só puderam chegar a esse resultado na medida em que procederam à aplicação de um conceito abstrato de valor ao entendimento das atuais con-

(13) COUTROT, Thomas. Dependência e Informalidade. Novos Estudos CEBRAP, n. 29, 1991, p. 159. dições do comércio internacional. Assim também as "concepções vulgares do imperialismo", que buscavam explicar a dinâmica econômica internacional pelo impulso das economias centrais para garantir a realização de sua produção ou para reverter a tendência de queda da taxa de lucro, baseavam-se na transposição direta das discussões sobre as "leis" de movimento geral da economia capitalista à realidade concreta, desprezando toda sorte de mediações econômicas e políticas. É para escapar de simplificações como essas que Egler (muito acertadamente) propõe analisar a dimensão espacial do desenvolvimento a partir da dinâmica da concorrência intercapitalista, o que permite articular uma série de mediações que atuam decisivamente na estruturação do espaço econômico mundial. Ganham destaque, nesse contexto, as estratégias movidas pelas grandes empresas e Estados nacionais para influir na definição das estruturas de mercado e dos padrões de concorrência, estratégias essas que abarcam as decisões de alocação de investimentos produtivos, as políticas de gestão da moeda e da força de trabalho e, enfim, todas as decisões que contribuem para diferenciar o espaço econômico mundial ${ }^{14}$.

A essência dos argumentos apresentados consiste, pois, em apontar a impossibilidade de operação da teoria do valor no âmbito das relações econômicas internacionais, em virtude das inúmeras mediações que, interferindo na dinâmica dessas relações, impedem o funcionamento de mecanismos que possam engendrar uma tendência à equalização das condições de rentabilidade do capital produtivo e dos níveis de produtividade do trabalho nesse âmbito. As teses que postulam a existência de mecanismos de transferência de

(14) EGLER, Claudio. Crise e questão regional no Brasil. Tese de Doutorado, Instituto de Economia da Universidade de Estadual de Campinas, 1993, pp. 47-75. 
valor em escala internacional (encampadas por Edward Soja sem maiores questionamentos) constituem portanto formas mecanicistas de aplicação da teoria do valor à problemática do subdesenvolvimento, já que não denotam nenhuma preocupação com as condições sociais que possibilitam a formação do valor.

Afloram assim as contradições, que são também sutis ironias, presentes no projeto teórico de Soja: primeiro, o resgate das teorias das trocas desiguais, ao invés de demonstrar a importância da geografia do capitalismo como objeto da teoria social crítica, consegue apenas elidir a mediação do Estado nacional no desenvolvimento das relações econômicas internacionais, como colocam Coutrot e Egler; segundo, seu esforço para dar uma forma mais concreta à teoria marxista, mediante a "espacialização" desta, parte do resgate de um modelo teórico que peca justamente pelo excesso de abstração, posto que trata a "lei" do valor como uma simples equação matemática, aplicável a qualquer contexto social.

Agora, considerando-se que a inoperância da teoria do valor em escala internacional já vinha sendo apontada por alguns estudiosos há cerca de vinte anos ${ }^{15}$, fica claro que não é correto atribuir as críticas dirigidas à vertente marxista da teoria do intercâmbio desigual unicamente à intransigência do "historicismo" em relação à "imaginação geográfica", tal como sugere Edward Soja ${ }^{16}$. Mesmo porque, boa parte das ob-

(15) Ver, por exemplo: CARDOSO, Fernando Henrique e SERRA, José. As desventuras da Dialética da Dependência. Estudos CEBRAP, n. 23, s.d., pp. 44 e 49 . Foi justamente por reconhecer essa inoperância que Francisco de Oliveira chegou a fazer a seguinte afirmação: "Creio, pessoalmente, que esta é uma das lacunas mais sérias na teoria marxista: a de explicar a formação do valor em escala internacional (...)". OLIVEIRA, Francisco de. A economia da dependência imperfeita. Rio de Janeiro, Graal, 1980, p. 37.

(16) Ver, por exemplo, as críticas de Schoeller à interpretação que Ernest Mandel faz da teoria do valor trabalho, assim como os comentários de Cesare Galvan às idéias desses dois autores. Ver: jeções feitas ao caráter a-histórico daquela vertente de pensamento não se pautavam pela denúncia de alguma forma de determinismo geográfico a ela atribuída. O que se combatia muitas vezes era a paradoxal combinação de determinismo econômico e voluntarismo político presente nas tentativas de estabelecer a necessidade da exploração centro-periferia e a impossibilidade do desenvolvimento dos países periféricos a partir da análise do movimento geral do capital ${ }^{17}$.

Concluindo, verifica-se que o procedimento utilizado por Soja para demonstrar a centralidade da exploração entre países e regiões para o funcionamento do capitalismo contorna as questões mais espinhosas (como a de explicar a formação do valor em escala internacional) e concentra a discussão em torno da dicotomia "historicismo" versus "imaginação geográfica", a qual não consegue nem de longe abranger a diversidade de orientações teórico-metodológicas mobilizadas para discutir a questão do subdesenvolvimento e da dependência na década de 70 mesmo considerando-se apenas o campo marxista. Não é tão simples quanto parece, pois, reafirmar a importância do espaço na teoria social crítica a partir da recuperação de certas versões marxistas da teoria do intercâmbio desigual. O mesmo se diga das tentativas para utilizar essas teorias na análise regional, como se verá a seguir.

SCHOELLER, W. op. cit.; GALVAN, Cesare G. "Tecnologia, Valor e Troca Desigual (Retomando um Artigo de Schoeller)". Estudos CEBRAP, n. 25, s.d.

(17) Ao criticar as idéias de Rui Mauro Marini, Fernando Henrique Cardoso e José Serra não deixam de notar que ele foi, provavelmente, o autor que melhor explicitou o reducionismo econômico subjacente às visões "estagnacionistas" e "catastrofistas" do fenômeno da dependência. A teoria de Gunder Frank sobre o "desenvolvimento do subdesenvolvimento" recai, segundo esses autores, no mesmo viés. CARDOSO, F. H. e SERRA, J. op. cit., pp. 76-77. Ver também: BELLUZZO, Luis Gonzaga de Mello. "Prefácio". In: GOLDENSTEIN, Lídia. Repensando a dependência. São Paulo, Paz \& Terra, 1994. 


\section{AS TEORIAS DAS TROCAS DESIGUAIS E A QUESTÃO REGIONAL: AINDA O PROBLEMA DAS TRANSFERÊNCIAS DE VALOR}

À luz dos argumentos apresentados na seção anterior, que problematizam a forma como Soja aplica seu conceito de "transferência geográfica de valor" ao âmbito das relações econômicas internacionais, pode-se indagar se esse conceito não seria aplicável à escala regional, já que, conforme indicado, as condições sociais de valorização do capital estariam presentes no caso de formações sociais específicas. Desse modo, nada impediria a utilização das teses do intercâmbio desigual para explicar o fenômeno das disparidades regionais dentro de um país, tal como o autor afirma ser possível.

Ainda nesse caso, porém, a resposta é negativa, pois a tese de que as assimetrias das condições de produção criam transferências de valor entre empresas e setores parte do equívoco de explicar o fenômeno do desenvolvimento desigual como produto agregado das "diferenças resultantes entre valor concretizado e preço"18. Já na década de 70 havia autores que apontavam essa falha nas teorias de Mandel, argumentando que o subdesenvolvimento deveria ser pensado do ponto de vista do desenvolvimento das forças produtivas e da formação de valor.

"A sociedade diretamente relacionada com cada processo produtivo será, portanto, o nível relevante para definir a produtividade média de trabalho e, portanto, o valor das mercadorias produzidas. Dentro daquele espaço econômico, se em alguma produção for empregado um tempo de

(18) SOJA, Edward W. Uma Interpretação Materialista da Espacialidade. In: BECKER, Bertha K. et alii (orgs). Abordagens políticas da espacialidade. Rio de Janeiro, UFRJ/Departamento de Geografia, 1983, p. 68. trabalho superior àquela média, parte desse tempo será perdida para a formação do valor, sendo este determinado para cada mercadoria pelo tempo médio necessário socialmente à produção. Se, pelo contrário, alguma unidade trabalhar com uma 'intensidade superior à média nacional', então à mesma duração do trabalho individual corresponderá um valor maior, por ser o valor determinado pela média social"19.

A chave da questão não reside portanto nas supostas diferenças entre o valor cristalizado nas mercadorias e os preços de venda fixados pela concorrência, mas sim nas diferentes intensidades do trabalho despendido pelos vários produtores. Daí que esse argumento pode ser formulado também de outra maneira, retomando-se algumas considerações sobre os pressupostos para a atuação da teoria do valor.

Com efeito, é preciso não esquecer que a operação dessa teoria pressupõe que os trabalhos concretos sejam homogeneizados para que se convertam em "trabalho abstrato". Essa homogeneização se dá na medida em que os vários trabalhos concretos e individuais são potencializados ou restringidos em função de uma medida dada pelo tempo médio de trabalho necessário para a produção das mercadorias. Os trabalhos individuais mobilizados por produtores que operam com baixos níveis de produtividade acabam assim sendo restringidos em função dessa média, de modo que as mercadorias desse produtor colocam-se no mercado como se fossem resultado de um menor número de horas trabalhadas. Em contraste, os trabalhos despendidos sob condições de maior eficiência são potencializados, e assim as mercadorias dos produtores que operam com níveis de produtividade mais elevados aparecem socialmente como se fossem fruto de um maior

(19) GALVAN, C. G. op. cit., p. 169. 
número de horas de trabalho despendidas sob condições inferiores. Não há, portanto, transferências de valor entre produtores que operam com níveis de produtividade muito díspares, mas sim diferenças na capacidade de geração de valor entre os diversos produtores, derivadas da posição relativa de cada um em relação ao tempo médio.

Mais uma vez, mostra-se incorreta a assertiva de que certas teorias acerca do desenvolvimento desigual foram menosprezadas devido a alguma espécie de dogmática "historicista" impregnada na teoria social crítica. O problema daquelas teorias reside antes na forma de interpretação da teoria do valor trabalho que lhes serve de suporte, a qual já vem sendo criticada por outras vertentes do pensamento marxista há pelo menos duas décadas.

$\mathrm{O}$ mesmo pode ser dito com respeito à tese de que o capitalismo depende do desenvolvimento geograficamente desigual para sobreviver a suas contradições intrínsecas. Essa tese remete de imediato à visão do capitalismo como um sistema hierarquizado de níveis de produtividade, já que seria principalmente a produtividade do trabalho em cada setor e empresa que definiria sua condição de "receptora" ou "transmissora" de valor; e, uma vez que a distribuição das atividades produtivas no espaço obedece a determinados padrões, o resultado agregado dessas diferenças de produtividade acabaria determinando também a posição de cada espaço regional no mecanismo das transferências de valor, qualificando-os como "pólos de acumulação" ou de "desvalorização".

Pela maneira como Edward Soja formula essa tese, fica difícil saber se o capitalismo depende principalmente do desenvolvimento desigual e das transferências geográficas de valor ou se é o incremento da produtividade (determinado principalmente pela introdução de progresso técnico no processo de produção) que garante a elevação da lucratividade e a sobrevivência do capitalismo.
Seja como for, faz-se necessário um breve retrospecto histórico para melhor entender essa questão. No período do capitalismo concorrencial, a relativa simplicidade do padrão tecnológico vigente, bem como o pequeno volume de capital requerido para a montagem de novas plantas industriais, conferia grande fluidez aos capitais e ao progresso técnico. Os capitais aplicados em setores menos lucrativos migravam com velocidade razoável para os setores que operavam com padrões tecnológicos e níveis de produtividade mais elevados, engendrando assim o que Marx denominou de "tendência à equalização da taxa de lucro". Com o advento do capitalismo monopolista, entretanto, essa situação se alterou profundamente, pois o volume de capital e os requisitos técnicos para a instalação de novas unidades produtivas se elevaram de forma tão acentuada que acabaram se tornando sérios obstáculos para a entrada de novos competidores nos setores mais lucrativos. Uma vez que a migração de capitais foi bloqueada, deixou de existir a tendência à formação de uma taxa média de lucro, visto que as condições técnicas de produção e a produtividade do trabalho tornam-se incontornavelmente heterogêneas. Mesmo que se considere apenas os produtores de um mesmo setor, a heterogeneidade das condições de produção continua tendendo a aumentar, pois as grandes empresas monopolistas passaram a ser detentoras quase exclusivas da capacidade de inovação tecnológica, o que lhes permite manter níveis de produtividade sistematicamente acima da média de seus concorrentes. Desse modo, uma empresa que detenha essa capacidade superior de inovação "passa a produzir um extravalor em relação ao valor de mercado, já que esta sua permanente situação de privilégio não permite que seu trabalho seja computado na média geral"20. Mas, se não exis-

(20) GIANNOTTI, J. A. op. cit., p. 57 (grifos nossos). 
te uma tendência à igualação dos níveis de produtividade e das taxas de lucro, nem por isso as mercadorias produzidas sob condições técnicas privilegiadas deixam de ser postas no mercado como comensuráveis em relação a todas as outras mercadorias. Tal situação simplesmente destrói a possibilidade de um trabalho social homogêneo, pois a troca de mercadorias já não reporta os valores de uso à uma produtividade média que funcione como medida objetiva da exploração do trabalho ${ }^{21}$.

A conclusão que se impõem a partir desse quadro é que Soja se equivoca quando sugere que o suposto processo de transferência geográfica de valor constitui a principal fonte de super-lucro, assegurando assim ao capitalismo a capacidade de sobreviver às suas próprias contradições. Os parágrafos acima colocam de maneira incisiva que são os investimentos maciços em pesquisa e desenvolvimento de novas tecnologias que constituem a estratégia central das empresas monopolistas para elevar sua lucratividade ${ }^{22}$.

(21) Tbidem.

(22) Ademais, o próprio Marx encontrou percalços para demonstrar que o capitalismo traria em seu bojo contradições que inviabilizariam sua reprodução. Isso ficou evidenciado quando ele reconheceu que o desenvolvimento das forças produtivas e o crescimento da massa de capital fixo engendrados pela industrialização eram tão grandes que acabavam colocando a questão de saber porque a taxa de lucro não declinava com a rapidez que seria de esperar tomando-se por base a tendência à queda da taxa de lucro. Daí ter concluído que “deve haver influências contrariantes em jogo, que cruzam e superam os efeitos da lei geral, dando-lhe apenas o caráter de uma tendência, motivo pelo qual também designamos a queda da taxa geral de lucro como uma queda tendencial". Entre essas contratendências, figura o próprio progresso técnico, que, incrementando a produtividade social da māo-de-obra, promove a desvalorização do capital constante e a ampliação da mais valia relativa. MARX, Karl. O capital: crítica da economia política. São Paulo, Abril Cultural, 1983, t. 1, v. III, pp. 177-189. Essa questāo gerou grandes celeumas entre os marxistas no pós-guerra, havendo os que afirmavam existir limites objetivos para o desenvolvimento daquelas contratendências e aqueles que negavam tais limites. Podese situar nessa segunda vertente os autores que pensavam a elevação da produtividade social da mão-de-obra como um processo que
Essa análise sobre as características mais gerais do capitalismo monopolista e o papel da tecnologia no processo de acumulação já é bastante conhecida, e Edward Soja com certeza está bem ciente dela. Mas a tese de que as inovações tecnológicas constituem a principal fronteira de acumulação no capitalismo contemporâneo (desempenhando assim o papel que outrora cabia ao expansionismo territorial) contradiz os esforços desse autor em demonstrar que são dos mecanismos de exploração inter-regional que brotam os mananciais de super-lucro. Soja procura se desvencilhar do problema com cautela, pois ao invés de tentar uma refutação dessa tese incômoda, prefere apenas enfatizar a importância da exploração entre regiões como fonte da superlucratividade.

Num dado momento, o autor age como se hesitasse em executar tal estratégia, afirmando que a desigualdade regional do desenvolvimento econômico sempre propiciou uma expressiva geração de super-lucros, e que isso continuava válido "(...) mesmo numa era em que a fonte primária da super-lucratividade pode ter passado a ser o desenvolvimento setorialmente desequilibrado" $^{\prime 23}$. É somente mais adiante que ele procederá de maneira realmente argumentativa. A partir da constatação de que, em face do atual pro-

terminaria negando progressivamente o valor de uso do trabalho social, fazendo assim com que a valorização do capital se autonomizasse frente à própria fonte do valor, que é o trabalho "vivo". Portanto, nāo é fácil dizer , como o faz Edward Soja, que a análise das "leis" de movimento do capital permite concluir que o capitalismo degeneraria rapidamente se não fosse a ação das transferências de valor, pois tudo depende de qual interpretação for dada à questão da queda da taxa de lucro na obra de Marx. Ver: MÂNTEGA, Guido. "A Lei da Taxa de Lucro: a Tendência da Queda ou a Queda da Tendência ?". Estudos CEBRAP, n. 16, 1976; TAVARES, Maria da Conceição. "O Movimento Geral do Capital (um Contraponto à Visão da Auto-Regulação da Produção Capitalista)". Estudos CEBRAP, n. 25, s.d.; GIANNOTTI, J. A. op. cit.

(23) SOJA, Edward W. Geografias pós-modernas: a reafirmação do espaço na teoria social crítica. op. cit., p. 203 (grifos nossos). 
cesso de redistribuição global das atividades econômicas, o regionalismo assumiu a forma de uma luta aguerrida para atrair investimentos, conclui que a "exploração do desenvolvimento desigual" se mantém como fonte asseguradora dos superlucros mesmo nos dias atuais ${ }^{24}$.

Ao fim e ao cabo, o desenvolvimento desigual e os mecanismos de transferência geográfica de valor já não parecem ser os únicos fatores capazes de explicar a longevidade do modo de produção capitalista, tal como Soja havia sugerido no momento em que, interessado em demonstrar a natureza "viva" e "dialética" do espaço, recuperara as teses de Ernest Mandel. Ao procurar estabelecer essa tese através de argumentos menos genéricos, Soja se viu forçado a reconhecer que o desenvolvimento tecnológico poderia desempenhar uma função, no mínimo, equivalente à dos processos de exploração inter-regional. Mas, ainda que tenha amenizado a ênfase na centralidade desses processos para o funcionamento do capitalismo, é preciso discutir se o argumento desenvolvido pelo autor para demonstrar a existência e a relevância da exploração inter-regional não estaria equivocado.

Com efeito, deduzir que a competição regional para atrair capitais revela a existência de grandes fluxos de transferência geográfica de valor, responsáveis pela geração de super-lucros nas regiões mais bem sucedidas, só é possível em se partindo do pressuposto de que a concentração de investimentos em determinadas regiões as transformam numa espécie de sorvedouros na-

(24) "O regionalismo nāo mais se enraiza apenas na resistência à homogeneizaçāo das tradições culturais, como o fazia, basicamente, no século XIX. Agora, ele faz parte do que Goodman chamou, apropriadamente, de 'guerras regionais por empregos e dólares' (...). Assim, a importância crescente da restruturação tecnológica e setorial não eliminou a exploração do desenvolvimento geograficamente desigual como fonte de manutenção dos superlucros." Ibidem, p. 209. turais do valor gerado em outras partes do mundo. O equívoco desse raciocínio reside precisamente na associação automática entre exploração e pobreza, como se esses dois elementos formassem algum tipo de "par dialético" mutuamente explicativo ${ }^{25}$.

Esse tipo de equívoco é um dos mais comuns dentro da tradição marxista, pois parte-se de uma leitura d'O Capital que estabelece uma correlação direta entre exploração e pobreza, de tal modo que, quanto mais intensa for a exploração da força de trabalho, maior terá de ser a miséria. Por extensão, as disparidades regionais poderiam ser explicadas pela sobreposição dos canais de extração de mais valia, já que a formação de áreas subdesenvolvidas apareceria como resultado da exploração de classes combinada com certos mecanismos de exploração entre regiões. Portanto, não é fortuita a forma como Soja chega a retomar certas teorias que, nos anos 70, explicavam as relações centro-periferia através de movimentos de transferência de valor que levariam à redução dos salários e das margens de lucro nos países periféricos, ao mesmo tempo em que ampliariam esses índices nos países centrais ${ }^{26}$.

Entretanto, existe uma outra forma de entender a lógica da acumulação, na qual se enfatiza a idéia de que, dado o contínuo revolucionamento do padrão tecnológico imposto pela dinâmica concorrencial (sobretudo nesta etapa monopolista), é possível constituir mecanismos para garantir o repasse de uma parcela dos ganhos de pro-

(25) Essa associação chega a ser explícita em certas passagens do livro de Soja, como no momento em que afirma categoricamente que “(...) quando há desigualdade geográfica no desenvolvimento capitalista, há transferências geográficas de valor. O fluxo líquido entre regiōes específicas pode não permanecer constante ao longo do tempo, e pode até inverter sua direçāo, mas as justaposições que induzem ao desenvolvimento e ao subdesenvolvimento continuam a existir em algum ponto do sistema". Ibidem, p. 139.

(26) Ibidem, p. 142. 
dutividade aos salários, através de acordos trabalhistas respaldados por coalizões sociais e políticas de amplo espectro ${ }^{27}$. A ação do Estado cumpre um papel decisivo no balizamento desse tipo de coalizão, atuando no sentido de garantir uma razoável desconcentração do excedente econômico (através de políticas de distribuição de renda e da prestação de serviços sociais) e também desempenhando o papel de mediador nas relações capital-trabalho, de modo a assegurar o respeito aos acordos trabalhistas. Nesse sentido, o salário e a renda dos trabalhadores podem crescer ao mesmo tempo em que se amplia o grau de exploração da força de trabalho (ainda que não na mesma proporção) ${ }^{28}$, não havendo motivos para afirmar que a concentração de investimentos e a melhor distribuição de renda numa dada região ou país só possa existir como produto da exploração de outras áreas.

O mesmo raciocínio se aplica à escala do Estado nacional, pois o problema das chamadas "disparidades regionais" não pode ser creditado a uma ação parasitária dos capitais concentrados nas regiões mais desenvolvidas sobre as o itras.

(27) O descolamento progressivo da valorização do capital em relação ao trabalho vivo (como indicado na nota 24 ) e a perda cła medida objetiva da exploração do trabalho (discutida anteriormente) são processos que destroem os mecanismos estritamente econômicos de regulação da produção capitalista, abrindo espaço para a politização crescente das relações econômicas. Como parte desse processo, “a miséria absoluta torna-se cada vez mais 'relativa' nos distintos países, com disparidades crescentes na organização social do trabalho e na distribuição 'politizada' das rendas do trabalho". TAVARES, M. C. op. cit., p. 17.

(28) Evidentemente isso não implica uma harmonização plena de interesses entre capital e trabalho, pois os conflitos entre corporaçōes e sindicatos em torno do controle dos processos de trabalho e dos repasses dos ganhos de produtividade são uma constante nos países desenvolvidos, mesmo entre as categorias profissionais de rendimentos mais elevados e mesmo que se considere apenas o período de auge do "fordismo". HARVEY, David. A condição pós-moderna: uma pesquisa sobre as origens da mudança cultural. São Paulo, Loyola, 1994, pp. 128-129.
Abandonando-se o pressuposto de que existe uma correlação linear entre exploração e pobreza, pode-se inverter o sentido da análise, de modo a estabelecer que são as condições sócio-econômicas de cada região, bem como as distintas experiências históricas regionais, que definem a dinâmica econômica de cada espaço regional vis-àvis sua forma de inserção na divisão territorial do trabalho.

Exemplos dessas duas formas de encarar a questão regional podem ser extraídos do próprio caso brasileiro, o qual tem inspirado um sem número de teorias que procuram explicar o desenvolvimento relativo do estado de São Paulo como resultado de um "imperialismo interno" 29 . Sem entrar nos pormenores dessa discussão, com suas muitas variantes, verifica-se que os intelectuais críticos dessa visão procuram justamente demonstrar que a riqueza relativa de São Paulo se deve ao próprio potencial econômico do estado, cuja origem reside num percurso histórico específico, dentro do qual se deu um desenvolvimento mais acentuado das relações capitalistas de produção ${ }^{30}$.

Portanto, a discussão sobre o desenvolvimento desigual, seja na escala das relações econômicas internacionais, seja na das. regionais, aparece invertida na perspectiva de Edward Soja: não é a exploração capitalista que produz regiões economicamente deprimidas para perpetuar-se; são os condicionantes históricos do movimento de expansão do capitalismo, mediados pelas es-

(29) Evidentemente, nem todas essas teorias estão baseadas no instrumental marxista, pois muitas delas apenas adaptam certas versões da teoria cepalina da deterioração dos termos de troca à questão dos desequilíbrios regionais, como já indicamos em outro texto. BESSA, Vagner C. e DINIZ FILHO, Luis L. Território e Política: as Mutaçōes do Discurso Regionalista no Brasil. Estudos Históricos, v. 8, n. 15, 1995.

(30) CANO, Wilson. Desequilíbrios regionais e concentração industrial no Brasil: 1930-1970. São Paulo, Global ; Campinas, UNICAMP, 1985, pp. $32-40$. 
pecificidades políticas e econômicas de cada região e país, que obstaculizam a reprodução do modelo de desenvolvimento das nações capitalistas centrais, entravando o progresso econômico e gerando a heterogeneidade social de que são vítimas as sociedades subdesenvolvidas. Desse ponto de vista, as concentrações regionais de pobreza não se devem a um processo de exportação do excedente econômico ali gerado. Pelo contrário, elas se originam da debilidade do desenvolvimento das relações capitalistas de produção e das condições particulares das lutas políticas nessas regiões, que restringem a capacidade de acumulação e concentram o excedente econômico (já relativamente baixo) em poucas mãos.

À luz dessas considerações, pode-se dizer que, ao procurar desenvolver uma nova versão da teoria do intercâmbio desigual, Soja simplesmente reciclou algumas visões problemáticas geradas no bojo do pensamento marxista a fim de munir a Geografia de instrumental teórico para desenvolver uma crítica abrangente da sociedade capitalista ${ }^{31}$. E vale acrescentar que, procedendo dessa maneira, o autor não fez senão reproduzir um vício bastante antigo dentro do movimento de renovação da Geografia, pois muitos geógrafos críticos já se mostraram propensos a

(31) Deve-se notar que, apesar das muitas críticas que já foram lançadas contra a teoria das trocas desiguais, não se deve imputar à CEPAL nenhuma responsabilidade pelo surgimento de certas modalidades bastante vulgares dessa teoria, tais como aquelas que, criticando as teses cepalinas, procuravam fundamentar a existência de uma "dialética da dependência". CARDOSO, F. H. e SERRA, J. op. cit., p. 42. Visões sintéticas das teorias da CEPAL e dos principais estudos sobre a questão da dependência podem ser encontradas em: GOLDENSTEIN, Lídia. Repensando a dependência. São Paulo, Paz \& Terra, 1994; FURTADO, Celso. O Subdesenvolvimento Revisitado. Economia e Sociedade, n. 1, 1992; RODRÍGUEZ, Octávio. O Pensamento da CEPAL: Síntese e Crítica. Novos Estudos CEBRAP, n. 16, 1986; CARDOSO, Fernando Henrique. As Tradições do Desenvolvimento-Associado. Estudos CEBRAP, n. 8, 1974. reformular sua disciplina a partir de teorias sobre a exploração inter-regional ${ }^{32}$.

Apesar dessa insistência histórica, os problemas para construir uma perspectiva de análise geográfica assentada no estudo de relações de exploração entre regiões são muito grandes. Além da dificuldade de aparar as arestas da teoria do intercâmbio desigual, a fim de adequá-la à teoria marxista do valor, subsiste o problema de como formular teoricamente a existência de mecanismos de exploração inter-regional sem incorrer num fetichismo do espaço. E a tentativa empreendida por Soja para escapar dessa armadilha, apesar do grande número de referências teóricas mobilizadas para tanto, não logrou ir além dos equívocos cometidos por grande parte dos estudiosos da questão regional.

\section{4. "DIALÉTICA SÓCIO-ESPACIAL" OU FETICHISMO DO ESPAÇO?}

Quando Soja propõe uma abordagem geográfica para a análise dos problemas regionais e urbanos, todos os seus esforços se dirigem no sentido de provar que é possível estabelecer a existência de mecanismos de exploração regional sem cair numa visão fetichista ou determinista da relação sociedade/espaço. No começo do seu livro, o autor procura prevenir-se de qualquer acusação de fetichismo arrolando uma série de citações eruditas, de autores que vão de Foucault a Berger, para demonstrar que o espaço (sobretudo nesta era "pós-moderna") é ativo e possui sua própria

(32) Basta lembrar que mesmo um autor sofisticado como David Harvey abraçou sem hesitação as idéias de Gunder Frank sobre as trocas desiguais, apesar das críticas que, já na década de 70, apontavam a fragilidade teórica e empírica da obra de Frank. HARVEY, David. A justiça social e a cidade. São Paulo, HUCITEC, 1980, pp. 198 e 225-226; Sobre as críticas à obra de Gunder Frank, ver: CARDOSO, F. H e SERRA, J. op. cit. pp. 41-42; CARDOSO, F. H. op. cit.; GOLDENSTEIN, L. op. cit., p. 31. 
"dialética". Não ver isso seria reproduzir um pensamento limitado, incapaz de acompanhar a "virada pós-moderna contra as determinações históricas" ${ }^{\prime 3}$. Todavia, ao elaborar sua tese sobre o desenvolvimento desigual e a transferência geográfica de valor, Soja não pode se escudar apenas em proposições genéricas, pois é imprescindível responder concretamente como é possível que lugares possam explorar lugares, já que a exploração econômica é uma relação social, que por isso só pode existir no âmbito das relações entre indivíduos, instituições, classes ou grupos sociais, mas nunca entre porções do espaço. A essa objeção, o autor responde da seguinte maneira:

“A questão de saber se regiões exploram regiões, portanto, deve ser afirmativamente respondida, mas essa afirmação só pode fazer sentido teórico e prático quando a regionalização e o regionalismo são vistos como processos hierarquicamente estruturados pelas relações fundamentais de produção. As regiões, nesse sentido, são pessoas, classes, formações sociais, coletividades, partes ativas e reativas da paisagem geográfica do capitalismo" ${ }^{\prime 34}$.

Depois de fazer desfilar tantas citações para demonstrar que o espaço não é um mero reflexo da sociedade, que ele influi ativamente nos processos sociais, o único meio encontrado por Soja para afirmar a possibilidade da exploração entre regiões, sem cair no fetichismo, é diluir o próprio conceito de região, que passa a ser apenas um outro nome para designar certos processos econômicos determinados pelas relações de produção. Nem poderia ser diferente, pois, para que se possa atribuir a determinadas parcelas do espaço a capacidade de desenvolver relações de exploração econômica, só mesmo criando uma iden-

(33) SOJA, E. W. Geografias pós-modernas: a reafirmação do espaço na teoria social crítica. op. cit., p. 32.

(34) Ibidem, p. 143. tidade entre categorias sócio-econômicas, tais como as de formação social, classe, etc., e o conceito de região ${ }^{35}$.

Na perspectiva do autor, todavia, essa forma cambiante de trabalhar conceitos aparece como virtude, já que ele propõe explicitamente o abandono da "lógica rigidamente categórica" como condição para chegar a uma verdadeira "dialética sócio-espacial". Isto significa que o espaço não deve ser pensado nem como estrutura distinta da vida social (com suas leis e determinações próprias) e nem como mero reflexo da sociedade, mas sim como "(...) um componente dialeticamente definido das relações de produção gerais, relações estas que são simultaneamente sociais e espaciais" ${ }^{\prime \prime 36}$. As relações de exploração do tipo centro-periferia, em todas as escalas, seriam assim "dialeticamente inseparáveis" da exploração de classe.

Ora, mas é preciso que se diga que enunciar a unidade dialética de dois conceitos ou processos não é o mesmo que demonstrá-la. E ainda que se argumente que é característica fundamental do discurso dialético a recusa a definir positivamente seu objeto, derivando daí a "opacidade" intrínseca a esse discurso, isso não exime o autor da necessidade de explicitar a racionalidade de suas conclusões. Não fosse assim, qualquer coisa poderia ser afirmada a partir de uma rápida referência à natureza dialética dos processos em foco, sem maiores explicações. No caso em pauta, o problema é justamente demonstrar, primeiro, por que as relações de produção seriam simultaneamente sociais e espaciais e, segundo, por que os processos de exploração entre classes e entre regiões haveriam de constituir uma

(35) Esse tipo de identificação é bastante comum entre os autores que se dedicam ao estudo da problemática regional, sejam eles ligados à tradição do marxismo ou da ciência regional. MARKUSEN, Ann R. Região e Regionalismo: um enfoque Marxista. Espaço \& Debates, Ano 1, n. 2, 1981.

(36) SOJA, E. W. Geografias pós-modernas: a reafirmação do espaço na teoria social crítica. op. cit., p. 99. 
unidade ao mesmo tempo contraditória e indissolúvel (ou seja, uma unidade dialética).

Ciente da necessidade de explicitar seu argumento, o autor afirma que, embora as regiões não sejam nunca homogeneamente "burguesas" ou "proletárias", seus sistemas produtivos localizados podem defini-las como "pólos de acumulação" ou de "desvalorização", criando assim relações de exploração análogas (mas não equivalentes) às que se entabulam entre as classes sociais ${ }^{37}$. Nesse sentido, a natureza intrinsecamente sócioespacial das relações gerais de produção, assim como a unidade entre exploração de classe e exploração inter-regional, acabam sendo postas pelos mecanismos de transferência geográfica de valor, já que estes seriam inerentes tanto ao processo de extração da mais valia quanto à assimetria das condições de produção vigentes entre firmas e setores, a qual levaria parte do valor gerado numa região a ser realizado em outra. Em tais mecanismos repousa, enfim, a essência da "dialética sócio-espacial" formulada pelo autor para fundamentar a existência de "regiões que exploram regiões".

Já foi discutido nas seções anteriores que não é pertinente aplicar de forma direta e sem mediações a teoria do valor de Marx à problemática do subdesenvolvimento (qualquer que seja a

(37) Ibidem, pp. 143-144. Além de explicitar a dialética das regiões como "sistemas sócio-espaciais", esse argumento procura contornar a impossibilidade (reconhecida pelo próprio autor) de estabelecer uma correspondência nítida entre classes e "regiões", a qual só pode ser encontrada, na melhor das hipóteses, em estudos sobre segregação urbana. MARKUSEN, A. R. op. cit. E isso sem considerar as enormes ambigüidades envolvidas na utilização do conceito de classe social para a análise das sociedades contemporâneas, derivadas da perda da medida objetiva da exploração capitalista e da politização das relações econômicas. As dificuldades dessa empreitada, bem como as maneiras possíveis de superá-las, já vêm sendo discutidas no interior da própria Geografia. HARVEY, David. "Entrevista a Mónica Arroyo e outros". Boletim Paulista de Geografia, n. 74,1996, p. 70. escala de análise), especialmente considerandose a elevada heterogeneidade dos processos produtivos que caracteriza a etapa do capitalismo monopolista. Mas, mesmo desconsiderando essa objeção, restaria ainda explicar de forma convincente por que essas transferências inter-setoriais deveriam ser vistas, simultaneamente, como transferências espaciais. Simplesmente porque as empresas que operam com níveis de produtividade mais elevados se localizam em lugares diferentes daquelas que são menos produtivas, ainda que muitas vezes a distância entre elas não supere os limites de uma mesma cidade? Sendo essa a resposta, fica claro que a unidade entre exploração inter-regional e exploração de classes não é determinada por nenhuma dialética, mas tão-somente por uma associação vaga entre os processos sociais e sua manifestação no espaço. Daí não ser demais lembrar que:

“(...) não há processos espaciais, mas os processos sociais manifestando-se sobre a superfície terrestre. $\mathrm{O}$ espaço terrestre apresenta uma série enorme e complexa de fenômenos naturais e sociais que se estendem sobre o espaço concreto" ${ }^{\prime 3}$.

É nesse sentido que se pode dizer que os esforços empreendidos por Soja para provar a existência de "regiões que exploram regiões" não vão além do mesmo equívoco básico que perpassa grande parte dos estudos de regionalização: tratar as relações (reais ou apenas supostas) que se estabelecem entre classes e grupos sociais como se fossem propriedades dos lugares que elas ocupam ou (o que dá no mesmo) tratar as "regiões" como se fossem sujeitos sociais. Para ir além desse tipo de raciocínio, dentro de uma perspectiva socialmente crítica, faz-se necessário retomar outras vertentes do marxismo e da própria Geografia.

(38) COSTA, Wanderley Messias e MORAES, Antonio Carlos Robert. A valorização do espaço. São Paulo, HUCITEC, 1984, p. 128 (grifo dos autores). 


\section{RECOLOCANDO A QUESTÃO DO DESENVOLVIMENTO DESIGUAL: CONTRIBUIÇÕES DO MARXISMO À GEOGRAFIA}

Em que pesem todas as fragilidades das teses de Soja, deve-se reconhecer que o impacto delas no âmbito da Geografia tem sido considerável. As razões disso parecem estar ligadas à forma como suas idéias sobre a exploração regional reavivam uma das maiores promessas trazidas pela Geografia marxista, qual seja, a de tornar essa disciplina apta a elaborar uma crítica "de raiz" ao capitalismo, partindo de uma análise centrada no espaço e nas relações deste com a sociedade. As várias teorias que procuraram fundamentar a existência necessária de mecanismos de exploração inter-regional sob o modo de produção capitalista serviam como uma luva a esse intento, e daí a atração que sempre exerceram sobre os geógrafos.

Ao se apropriarem das teorias que procuravam qualificar o subdesenvolvimento como resultado da exploração centro-periferia, contudo, os geógrafos acabaram incorrendo no mesmo equívoco de vários economistas e sociólogos de orientação marxista que se dedicaram ao estudo dessa problemática, qual seja, o de pressupor que o caráter desigual e combinado do desenvolvimento capitalista se deve a alguma lei férrea intrínseca ao movimento do capital.

Melhor seria partir de outra leitura dos clássicos do marxismo, segundo a qual a riqueza dos estudos de Marx e Lênin reside justamente no esforço para compreender a realização histórica das chamadas "leis de funcionamento do capitalismo". Quer dizer, a originalidade da perspectiva marxista não está na busca de leis econômicas que regem os processos sociais, mas sim na articulação da teoria da valorização do capital com o estudo da gênese do capitalismo em cada país, de modo a identificar e hierarquizar os processos históricos que engendram as condições sociais indispensáveis para a vigência daquelas "leis"39. Partindo desse ponto de vista alternativo, tornase possível assentar os estudos sobre o desenvolvimento desigual sobre novas bases:

"Ora, a questão a ser resolvida não é 'o capital' no espaço, mas 'o desenvolvimento do capitalismo no espaço'. A diferença é imensa: se o primeiro caso fosse pertinente, seria o caso de inquirir sobre leis gerais; no segundo há que ter em mente que a história não importa apenas como condição inicial, é da história que estamos falando. Isto não significa obrigatoriamente ancorarse numa proposta historicista, mas significa reconhecer que a elaboração teórica sobre este processo não tem como fugir da fixação de suas condições históricas" ${ }^{\prime \prime 0}$.

Não se trata, portanto, de tentar construir uma teoria geral para explicar o fenômeno das disparidades sócio-econômicas verificadas em várias escalas e nem muito menos de postular, sob o pretexto de fazer juz às particularidades históricas, uma volta pura e simples ao empirismo. O desafio da Geografia é produzir uma teorização de fundo sobre o processo de valorização do espaço que permita articular, no bojo de estudos concretos sobre o problema da difusão do desenvolvimento capitalista, as inúmeras mediações econômicas,

(39) Daí a importância conferida, nessa linha de interpretação, às discussões relativas aos "momentos lógicos" da gênese do capitalismo e ao conceito de "vias de desenvolvimento". OLIVEIRA, Carlos Alonso Barbosa. O processo de industrialização: do capitalismo originário ao atrasado. Tese de Doutorado, Instituto de Economia da Universidade Estadual de Campinas, 1985.

(40) PACHECO, Carlos Américo. A questão regional brasileira pós 1980: desconcentração econômica e fragmentação da economia nacional. Tese de Doutorado, Instituto de Economia da Universidade Estadual de Campinas, 1996, p. 22 (grifos do autor). Note-se que, na passagem citada, o termo "historicista" está sendo empregado de acordo com a acepção mais comum nos estudos sobre o desenvolvimento, conforme indicado na nota 5 . 
políticas e até culturais que concorrem para diferenciar o espaço geográfico.

Um ponto de partida bastante fértil para atingir essa meta é tomar o processo social de valorização do espaço como objeto de estudo da Geografia. Abstraindo-se as particularidades históricas e geográficas que compõem a totalidade da vida social, verifica-se que existe um processo universal e, de certo modo, atemporal de valorização do espaço ${ }^{41}$. Para analisar esse processo, é preciso considerar que o espaço terrestre, mesmo quando ainda intocado pela ação humana, possui um certo valor potencial, um volume variável de recursos que podem ser apropriados pelo homem para a produção de suas condições de existência. À medida que a sociedade cria formas materiais que se fixam ao solo (estradas, edifícios, fábricas, etc.) ocorre uma agregação de valor ao espaço, a qual tende a prosseguir mesmo depois que o substrato natural já foi transformado pelo trabalho humano, com um acúmulo constante de valor.

Essa forma de valorização pode ser compreendida como um processo que se realiza no jogo permanente entre o "valor contido", que expressa todo o valor já existente numa determinada unidade de área, e o "valor criado", conceito que designa a aplicação de capital ao espaço. Noutras palavras, o valor contido expressa o "valor do espaço" (recursos naturais, infraestrutura, áreas plantadas, etc.), enquanto o segundo se refere ao "valor no espaço", isto é, ao valor que é aplicado sobre uma área qualquer num dado período, parte do qual é fixado ao solo e passa a fazer parte do valor contido ${ }^{42}$.

(41) Embora este conceito tenha uma conotação estreitamente vinculada à economia, é preciso destacar que a valorização do espaço se realiza em três esferas distintas da vida social, isto é, a economia, a política e a cultura. Para os propósitos deste texto, porém, basta detalhar o aspecto econômico desse processo.

(42) COSTA, Wanderley M. e MORAES, Antonio C. R. op. cit.
O valor criado é assim um conceito instrumental, um recurso de método que consiste em efetuar um recorte temporal para analisar o processo de valorização do espaço, enfocando o momento em que se dá a agregação de valor ao solo. Além desse recorte temporal, o estudo concreto da valorização do espaço requer ainda dois outros conceitos básicos, que definem os desdobramentos mais gerais desse processo: a "fixação geográfica de valor" e a "transferência geográfica de valor".

O conceito de fixação de valor remete imediatamente ao processo de criação das chamadas "rugosidades", isto é, a construção de formas materiais que, uma vez fixadas ao solo, passam a fazer parte do espaço construído ${ }^{43}$. Neste ponto, resgata-se uma das mais instigantes contribuições da Geografia Crítica para o avanço da disciplina, qual seja, a possibilidade de compreender como as formas materiais construídas pela sociedade (e desigualmente distribuídas na superfície terrestre) terminam por influir na própria dinâmica da vida social. Tal influência, de acordo com a clássica formulação de Milton Santos, se manifesta sob a forma de uma "inércia dinâmica" do espaço, o que significa dizer que as formas construídas, embora contendo os determinantes históricos das sociedades que as engendraram, tendem a perdurar mais do que esses determinantes historicamente datados, condicionando assim, até certo ponto, os processos sociais ocorridos posteriormente ${ }^{44}$. Nesse sentido, o estudo da fixação de valor permite abordar os efeitos que a

(43) Segundo a conceituação de Milton Santos, "as rugosidades sāo o espaço construído, o tempo histórico que se transformou em paisagem, incorporado ao espaço". SANTOS, Milton. Por uma geografia nova: da crítica da geografia a uma geografia crítica. São Paulo, EDUSP / HUCITEC, 1978, p. 138.

(44) É interessante observar que, enquanto Edward Soja procura demonstrar a natureza ativa das configurações espaciais através da "espacialização" de certos processos econômicos, Milton Santos abre 
concentração desigual dos investimentos exerce sobre a organização da economia e da sociedade.

Para compreender como se processa esse acúmulo diferencial de valor na superfície terrestre, faz-se útil o conceito de "transferência geográfica de valor". Mas ao invés de conceber essa transferência como um processo de exploração entre regiões, inerente à lógica do movimento do capital, trata-se de pensá-la de um ponto de vista eminentemente histórico, através do qual se analisam as condições que levaram determinados grupos sociais a aplicar parte do excedente econômico gerado numa dada área em atividades produtivas a serem criadas ou desenvolvidas em outras partes do mundo. E vale dizer que as decisões tomadas no sentido de proceder a essa transferência de valor não se vinculam apenas às expectativas de lucro dos agentes econômicos, mas também aos interesses políticos e estratégicos dos Estados nacionais ${ }^{45}$ - como ressaltam todos os clássicos da Geografia Política ${ }^{46}$.

Nesse sentido, a análise de situações históricas concretas (para usar uma expressão bastante cara à tradição marxista) permite identificar as

vias muito mais promissoras para chegar a esse resultado, como quando afirma por exemplo que: "Por inércia dinâmica queremos significar que as formas são tanto um resultado como uma condição para os processos". Ibidem, p. 148.

(45) A colonização do Brasil fornece um bom exemplo de como interesses econômicos e geopolíticos podem se combinar para pôr em movimento grandes fluxos intercontinentais de mercadorias, exponencializando a acumulação de capital na Metrópole, e engendrar processos de fixação e transferência geográfica de valor capazes de estruturar um sistema produtivo complexo numa região praticamente virgem do planeta. MORAES, Antonio Carlos Robert. "Geopolítica da Instalação Portuguesa no Brasil". Histórica: Revista do Arquivo, n. 1, 1993.

(46) Uma das contribuições teóricas mais importantes da Geografia Política é justamente a ênfase no papel do Estado como organizador do território e na relativa autonomia da ação estatal em relação aos interesses dos capitais nacionais. COSTA, Wanderley Messias. Geografia política e geopolítica: discursos sobre o território e o poder. São Paulo, HUCITEC/EDUSP, 1992. condições sob as quais os agentes econômicos e políticos acionam mecanismos de transferência e de fixação de valor que, a longo prazo, alteram a forma de distribuição das atividades produtivas e a própria organização do espaço. Mas para ajustar o enfoque analítico às situações concretas, com toda a sua riqueza de mediações, é necessário antes satisfazer duas exigências teóricas fundamentais.

A primeira delas consiste em historicizar o conceito de valorização do espaço, a fim de captar a especificidade que esse processo assume sob o modo de produção capitalista. Para tanto, duas características essenciais do capitalismo precisam ser ressaltadas na análise: a expansividade tendencial das relações de produção capitalistas e a centralidade que o capital, em virtude dessa tendência, assume na moldagem dos processos sociais. Isto significa que, por um lado, o capitalismo tende a sujeitar progressivamente todos os lugares da terra à lógica da acumulação, podendo então ser definido, desse ponto de vista, como uma sociedade mercantil que tende à exaustão espacial. Por outro lado, o capital se caracteriza pela seletividade espacial, no sentido de que as várias formas de capital produtivo (sobretudo os grandes capitais) tendem a se concentrar nos lugares que oferecem condições privilegiadas para maximizar a acumulação. Nesse contexto, a especificidade do processo de valorização do espaço sob o capitalismo reside na sua lógica simultaneamente homogeneizadora e diferenciadora. Os lugares são especializados e hierarquizados, mas atuam numa sincronia dada por um sistema econômico de âmbito global. Essa é a manifestação mais visível do caráter desigual e combinado do desenvolvimento econômico capitalista.

A segunda exigência que precisa ser satisfeita para o estudo concreto da valorização do espaço é a definição de um recorte analítico que 
permita captar a singularidade dos lugares e os processos que a engendram. Para tanto, é imprescindivel abandonar as perspectivas excessivamente calcadas na categoria "espaço" ${ }^{\text {"47 }}$, colocando no centro da análise um conceito dotado de conteúdo empírico mais preciso. O conceito de formação territorial, talvez mais do que qualquer outro, cumpre bem essa tarefa de servir como fio condutor das análises voltadas para a historicidade dos processos de valorização do espaço, em seus desdobramentos econômicos, políticos e culturais con$\operatorname{cretos}^{48}$. Numa palavra, pode-se dizer que:

“(...) enquanto a valorização do espaço aparece como o horizonte teórico genérico de indagação, a formação territorial desenha-se como objeto empírico, o ajuste de foco naquela ótica angular de se captar o movimento histórico. Uma abordagem que busca apreender a valorização do espaço em manifestações singulares sincronicamente analisadas" ${ }^{\prime \prime 9}$.

Ao conferir esse papel ao conceito de formação territorial, a proposta apresentada se in-

(47) A Geografia Crítica empreendeu valiosos questionamentos sobre a maneira tradicional de empregar categorias tais como as de paisagem, região e outras, mas acabou também negligenciando a necessidade de reelaborar teoricamente essas e outras categorias utilizadas pela Geografia Tradicional. SANTOS, Milton. Técnica espaço tempo: globalização e meio técnico-científico informacional. Sāo Paulo, HUCITEC, 1994, p. 173.

(48) É certo que o processo de globalização da economia se constitui através de uma série de transformações que convergem no sentido de: a) ampliar a "permeabilidade" das fronteiras nacionais aos fluxos de mercadorias e de capitais financeiros; b) internacionalizar os próprios processos produtivos, tendendo assim a criar os chamados "produtos mundiais". Contudo, tal processo não elimina, mas requalifica, o papel dos territórios como elementos econômicos e geográfico - políticos capazes de influenciar o atual movimento de redefinição da divisão internacional do trabalho. DINIZ FILHO, Luis Lopes. O Papel das Formações Territoriais no Processo de Globalização: Notas de Caráter Geográfico Político sobre o caso Brasileiro. Experimental, Ano 1, n. 2, 1997.

(49) MORAES, Antonio Carlos Robert de. A Geografia como Históıia Territorial. Universidade de São Paulo, mimeo. s.d. sere na perspectiva que coloca o Estado nacional como escala de análise privilegiada da Geografia. Mas é claro que essa perspectiva não é incompatível com a utilização de mais uma escala de análise, a regional, como instrumento para o estudo das disparidades sócio-econômicas e tensões regionalistas que se fazem presentes no interior dos próprios territórios nacionais ${ }^{50}$. Isso é particularmente verdadeiro no período contemporâneo, em que a perspectiva regional mostra-se bastante útil para captar o atual movimento de diferenciação interna dos territórios, engendrado pelo processo de globalização da economia ${ }^{51}$.

Desenham-se assim os parâmetros necessários para o estudo concreto dos processos de desenvolvimento desigual e combinado sob o modo de produção capitalista. Ao invés de se conceber esse processo como uma decorrência lógica das leis de movimento do capital, parte-se do princípio de que a criação das desigualdades é fruto das particularidades que condicionam o movimento histórico de mundialização do capitalismo e de difusão do progresso técnico nesse espaço econômico mundializado ${ }^{52}$. Entre essas particularidades, a que interessa mais de perto à Geografia são os diferenciais de valor contido entre os lugares, em termos de recursos naturais disponíveis e de valor fixado. É no movimento de constituição e organização dos territórios que se dá a síntese dessas duas ordens de determinações, quais sejam, os

(50) Ver: MARTIN, André Roberto. As fronteiras internas e a "questão regional" no Brasil. Tese de Doutorado, Departamento de Geografia da Faculdade de Filosofia, Letras e Ciências Humanas da Universidade de Sāo Paulo, 1993.

(51) DINIZ FILHO, L. L. op. cit.

(52) "A rigor, o subdesenvolvimento é uma variante do desenvolvimento, melhor, é uma das formas que historicamente assumiu a difusão do progresso técnico". FURTADO, C. op. cit., p. 12. Vale ressaltar que essa concepção traz implícita “(...) uma visão espaço-temporal, já que centro e periferia se constituem historicamente como resultado da forma pela qual o progresso técnico se difunde na economia mundial". EGLER, C. op. cit., p. 35. 
condicionantes do processo de expansão do capitalismo, em suas várias fases, e a singularidade dos lugares e das sociedades que vão sendo incorporadas ao espaço de relações capitalistas, homogeneizando-se e diferenciando-se ainda mais à medida que se inserem. Dentro desse movimento permanente, podem ser identificadas certas formas de apropriação de excedente ou de transferências monetárias entre diferentes sistemas econômicos nacionais, mas estes fenômenos só podem ser compreendidos através de uma perspectiva histórica, centrada na dinâmica das lutas políticas, não numa visão economicista baseada nas leis de movimento do capital ${ }^{53}$.

Em conseqüência, a Geografia pode estudar fenômenos e contradições sociais que são intrínsecos ao modo de produção capitalista, mesmo prescindindo de qualquer versão reciclada da teoria do intercâmbio desigual. Vale dizer que isso abre para o geógrafo possibilidades de atuação teórica e prática muito mais férteis do que uma visão estreitamente focada na inevitabilidade da exploração inter-regional. Ao invés de repetir indefinidamente um discurso vago sobre a importância do "espaço" para a compreensão das contradições sociais, o geógrafo pode mergulhar na tarefa de realizar estudos concretos sobre o pro-

(53) A título de exemplo, pode-se lembrar que a crise do endividamento externo, que se abateu sobre os países subdesenvolvidos a partir do final da década de 70, engendrou elevadas transferências de recursos destes para as naçōes centrais, sob a forma do repatriamento de lucros e do pagamento dos serviços e juros da dívida. Isso foi conseqüência da escassez de oportunidades de investimento produtivo em escala internacional (que se seguiu à maturação da onda de inversões realizadas no pós guerra) e das pressões exercidas pelos organismos multilaterais para que os países endividados efetuassem o "ajuste" de suas economias. Portanto, é possível identificar, sob condições históricas bem determinadas, movimentos de transferência de renda entre distintas economias nacionais (mediatizados pelo sistema financeiro internacional) partindo da análise dos condicionantes políticos e econômicos da dinâmica da acumulação em escala mundial e suas repercussões em cada país. CASTRO, Armando Barros de. O Conceito de Desen- cesso de valorização do espaço e os problemas sociais atinentes à forma especificamente capitalista pela qual ele se desenvolve. Em lugar de se enclausurar numa posição teórica que esvazia ou enfraquece a importância do planejamento público - já que a suposta necessidade de exploração inter-regional travaria as tentativas de romper com os desequilibrios entre regiões ${ }^{54}-$, o geógrafo tem diante de si a perspectiva de, conhecendo os limites impostos pelas circunstâncias históricas do momento, intervir eficazmente na discussão e encaminhamento das políticas territoriais do Estado. Essa forma de atuação política é inclusive mais coerente com a conjuntura atual, em que os geógrafos críticos, juntamente com boa parte das esquerdas, elegeram a luta contra o desmonte neoliberal do Estado planejador como seu principal front de batalha. A consolidação das inovações trazidas pela Geografia Crítica exige, portanto, maior arejamento teórico, acompanhado do retorno urgente aos estudos concretos.

volvimento: Continuidade e Mudanças na América Latina. Corea E Iberoamérica, v. 4, 1988.

(54) Segundo Edward Soja, a importância do desenvolvimento desigual para a geração e extração de super-lucros faz com que o planejamento regional entre em contradição com o papel exercido pelo Estado como estimulador do processo de acumulaçāo capitalista. SOJA, E. W. Geografias pós-modernas: a reafirmação do espaço na teoria social crítica. op. cit., p. 203. 


\section{BIBLIOGRAFIA}

BELLUZZO, L. G. de M. Prefácio. In: GOLDENSTEIN, Lídia. Repensando a dependência. São Paulo, Paz \& Terra, 1994.

BESSA, V. de C. DINIZ FILHO, L. L. Território e Política: as Mutações do Discurso Regionalista no Brasil. Estudos Históricos, v. 8, n. 15, 1995.

CANO, W. Desequilíbrios regionais e concentração industrial no Brasil: 1930-1970. São Paulo, Global; Campinas, UNICAMP, 1985.

CARDOSO, F. H. e SERRA, J. As desventuras da Dialética da Dependência. Estudos CEBRAP, n. 23, s.d.

CARDOSO, Fernando Henrique. As Tradições do Desenvolvimento-Associado. Estudos CEBRAP, n. 8, 1974.

CASTRO, A. B. de. O Conceito de Desenvolvimento: Continuidade e Mudanças na América Latina. Corea \& Iberoamérica, v. 4, 1988.

COSTA, W. M. da; MORAES, A. C. Robert. A valorização do espaço. São Paulo, HUCITEC, 1984.

COSTA, W. M. da. Geografia política e geopolítica: discursos sobre o território e o poder. São Paulo, HUCITEC/EDUSP, 1992.

COUTROT, T. Dependência e Informalidade. Novos Estudos, n. 29, 1991.

DINIZ FILHO, L. L. O Papel das Formações Territoriais no Processo de Globalização: Notas de Caráter Geográfico Político sobre o caso Brasileiro. Experimental, Ano 1, n. 2, 1997.

EGLER, C. Crise e questão regional no Brasil. Tese de Doutorado, Instituto de Economia da Universidade Estadual de Campinas, 1993.

FURTADO, C. O Subdesenvolvimento Revisitado. Economia e Sociedade, n. 1, 1992.

GALVAN, C. G. Tecnologia, Valor e Troca Desigual (Retomando um Artigo de Schoeller). Estudos CEBRAP, n. 25, s.d.

GIANNOTTI, J. A. A Sociabilidade Travada. Novos Estudos CEBRAP, n. 28, 1990.

GOLDENSTEIN, L. Repensando a dependência. São Paulo, Paz \& Terra, 1994.

HARVEY, D. A condição pós-moderna: uma pesquisa sobre as origens da mudança cultural. São Paulo, Loyola, 1994. . A justiça social e a cidade. São Paulo, HUCITEC, 1980. Entrevista a Mónica Arroyo e Outros. Boletim Paulista de Geografia, n. 74, 1996.
HIRSCHMAN, A. O. A economia como ciência moral e política. São Paulo, Brasiliense, 1986.

MÂNTEGA, G. A Lei da Taxa de Lucro: a Tendência da Queda ou a Queda da Tendência? Estudos CEBRAP, n. 16, 1976.

MARKUSEN, A. R. Região e Regionalismo: um Enfoque Marxista. Espaço \& Debates, Ano 1, n. 2, 1981.

MARTIN, A. R. As fronteiras internas e a "questão regional" no Brasil. Tese de Doutorado, Departamento de Geografia da Faculdade de Filosofia, Letras e Ciências Humanas da Universidade de São Paulo, 1993.

MARX, K. O capital: crítica da economia política. São Paulo, Abril Cultural, 1983, t. 1, v. III (Coleção "Os Economistas").

MORAES, A. C. R. A Geografia como História Territorial. Universidade de São Paulo, mimeo. s.d. . Geopolítica da Instalação Portuguesa no Brasil. Histórica: Revista do Arquivo, n. 1, 1993.

OLIVEIRA, C. A. B. O processo de industrialização: do capitalismo originário ao atrasado. Tese de Doutorado, Instituto de Economia da Universidade Estadual de Campinas, 1985.

OLIVEIRA, F. de. A economia da dependência imperfeita. Rio de Janeiro, Graal, 1980.

PACHECO, C. A. A questão regional brasileira pós 1980: desconcentração econômica e fragmentação da economia nacional. Tese de Doutorado, Instituto de Economia da Universidade Estadual de Campinas, 1996.

RODRÍGUEZ, O. O Pensamento da CEPAL: Síntese e Crítica. Novos Estudos CEBRAP, n. 16, 1986.

SANTOS, M. Por uma geografia nova: da crítica da geografia a uma geografia crítica. São Paulo, Edusp/Hucitec, 1978.

. Técnica espaço tempo: globalização e meio técnico-científico informacional. São Paulo, Hucitec, 1994

SCHOELLER, W. Subdesenvolvimento e Troca Desigual no Mercado Mundial. Estudos CEBRAP, n. 22, s.d.

SOJA, E. W. Geografias pós-modernas: a reafirmação do espaço na teoria social crítica. Rio de Janeiro, Jorge Zahar, 1993.

. Uma Interpretação Materialista da Espacialidade. In: BECKER, Bertha K. et alii (orgs). Abordagens políticas da espacialidade. Rio de Janeiro, UFRJ/Departamento de Geografia, 1983. 
TAVARES, M. da C. O Movimento Geral do Capital (um Contraponto à Visão da Auto-Regulação da Produção Capitalista). Estudos CEBRAP, n. 25, s.d.
TRINDADE JR., S. C. da. Resenha Bibliográfica: Geografias Pós-Modernas: a Reafirmação do Espaço na Teoria Social Crítica. Boletim Paulista de Geografia, n. 74, 1996.

\begin{abstract}
This article raises theoretical criticisms on the way the concept of geographical transfer of value was dealt by Edward Soja in his book Postmodern Geographies: the reassertion of space in critical social theory. Basically, it follows two lines of reasoning: a) demonstration of the incompatibility between the theory of value and the attempts to characterize uneven development as a product of certain mechanisms of core-periphery exploitation; b) indication that this author's efforts, in order to prove that there are regions that exploit regions, are a form of space fetishism.

At the end of the text, a proposition of an analysis, alternative to the one of Soja and based on other interpretations of Marxism and on the Geography of the uneven development issue, is presented.
\end{abstract}

